\title{
China Word: Vocabulary Quiz Game for Promoting Chinese Vocabulary Memory among 10th Grade Students
}

\author{
Dr. Thanakorn Uiphanit, Suan Sunandha Rajabhat University, Thailand, thanakorn.ui@ssru.ac.th, \\ ORCID: 0000-0002-6782-080X \\ Nattawadee jansibsee , Wat bo ktu"kuruparachasan" School, Thailand, namnam111038@gmail.com, \\ ORCID: 0000-0002-8208-1320 \\ Dr. Pattarasinee Bhattarakosol ,Chulalongkorn University, Thailand, pattarasinee.b@chula.ac.th, ORCID: \\ 0000-0002-9938-028X
}

Thatsanan Chutosri , Suan Sunandha Rajabhat University, Thailand, thatsanan.ch@ssru.ac.th, ORCID: 0000-0003-2364-723X

Pongpisid Liangyoo , Suan Sunandha Rajabhat University, Thailand, pongpisid.li@ssru.ac.th@ssru.ac.th, ORCID: 0000-0001-7323-2652

Pongsakorn Kingsuwankul , Suan Sunandha Rajabhat University, Thailand, pongsakorn.ki@ssru.ac.th, ORCID: 0000-0003-3280-679X

Natcha Wattanaprapa, Suan Sunandha Rajabhat University, Thailand,natcha.wa@ssru.ac.th, ORCID: 0000-0002-3667-7094

Wannarat Bunchongkien, Suan Sunandha Rajabhat University, Thailand, wannarat.bu@ssru.ac.th, ORCID: 0000-0003-2333-0064

\begin{abstract}
The main purpose of this research is to develop a mobile application game, China Word, to promote the memorization of Chinese vocabulary for 10th grade students. The comparison between students' scores before and after learning with the game is used to determine success or failure in this study. The sample group was randomly collected from 10th grade students at a volunteer school in Suphanburi Province, Thailand. Sixty students participated in this study. Sixty students were separated in two groups, first thirty students group was the control group and second thirty students group was the experimental group. The control learned Chinese with lecture while the experimental group learned Chinese with the China Word game. In addition, an achievement test and a satisfaction questionnaire were deployed in this experiment as tools to measure students' accomplishments. Then, simple statistics, such as averages, percentages, standard deviations, and t-test independence, were calculated. The result indicates that the experimental group attains higher learning achievement than the control group at a $95 \%$ confidence level.
\end{abstract}

Keywords: Chinese, Educational games, Learning achievement, Vocabulary game, Vocabulary memory Received: 17.11.2020 Accepted: 21.12.2020 $\quad$ Published: 10.01.2021

\section{INTRODUCTION}

China is the country with the highest population in the world [record from United Nations, (23 Feb 2020) (Worldometers, 2020), and the formal language of Chinese is Mandarin. At the present time, China has lead the international trade and economic growth in the world such as Thailand, Japan and South Korea. In addition, this country is going to be the leader in the world economy, including science and technologies. Therefore, knowing Mandarin is a good opportunity to perform business cooperation with both the Chinese government and private sections around the world. Nevertheless, it is the tremendous challenge of every learner in learning Mandarin's vocabulary.

Since Chinese people are all around the world, Mandarin is not used only in China, but it can be heard in every country. Therefore, it can be said that Mandarin is a well-known and widely used language around the world. According to the World Economic Impact, there is an urgent for educational institutes, both national and international, to include Mandarin in their curriculums, especially at the secondary level (10th grade-12th grade). Therefore, many schools have included Chinese learning as an elective subject for students to study in the normal classes since 2008, and it is assumed that the educational institutes provide learners with competent lecturers and other learning materials. With this policy, the students responded with keen, wide interest in the new language option (Kanoksilapatham, 2011). Moreover, various studies have focused on improving Chinese lessons to increase the efficiency of learners and teachers. In addition, research has been performed that compared the Chinese learning 
proficiency between learning with games and learning with normal classes among undergraduate students at Silpakorn University (Pianpitak, 2012). This research indicates that learning using games is more efficient than learning using normal teaching methods. Nonetheless, implementing new media or teaching materials can increase interest in lessons, although it is still not as exciting as learning from games (Begg, Dewhurst, \& Macleod, 2005; De Freitas, 2018; Ebner \& Holzinger, 2007; Rashid, Salleh, \& Noor, 2018)

In the past decade, teaching Chinese language by lecturing in front of a classroom is the traditional method that teachers use to teach students. Nonetheless, teaching by lecture can't help some students' understanding since characters and vocabulary are too hard to remember. Consequently, some students struggle, are bored, and ignore lessons, which may decrease their learning. Thus, to solve these problems, many teaching methods and tools are available on the Internet, especially on YouTube.com, such as the YouTube channel "Learn Chinese Hobbies in Mandarin" (Terantino, 2011), the social media "WeChat" (Jin, 2018), the card game "Digital flash card" (Zhu, 2010) and the video game "MicroMandarin". (Edge, Searle, Chiu, Zhao, \& Landay, 2011)

Based on previous studies, the current researchers deploy an academic game to promote the learning of Chinese vocabulary; this game is categorized as a vocabulary game. The vocabulary game is composed of cartoons and animations (Edge, Searle, Chiu, Zhao, \& Landay, 2011; Yeh, \& Wang, 2013) because learning using videogames can enhance students' enjoyment and fun (Edge, Searle, Chiu, Zhao, \& Landay, 2011; Rashid, Salleh, \& Noor, 2018), increase students' interest in the learning process (Kanoksilapatham, 2011) and improve their vocabulary memorization (Edge, Searle, Chiu, Zhao, \& Landay, 2011).

This research is interested in defining and solving the problems when learning the Chinese language using the standard method. The sample students in this study are 10th grade students from school A in Suphanburi Province, Thailand. The interview results show that the standard teaching method is too dull to improve focus, the grammar is too hard, and teachers lack the appropriate media to motivate students' interest in learning. Therefore, gaming applications should be used to improve the interest of learners in learning Chinese vocabulary, improve students' remembrance of Chinese vocabulary and increase enthusiasm among students (Prensky, 2001; Rashid, Salleh, \& Noor, 2018; Wu, \& Huang, 2017; Yeh, \& Wang, 2013). The main objective of this research is to design and develop a Chinese characters and vocabulary learning game in mobile application, "China Word", to study the performance of game after learning with the game, and to study students' satisfaction in game.

\section{Research Framework}

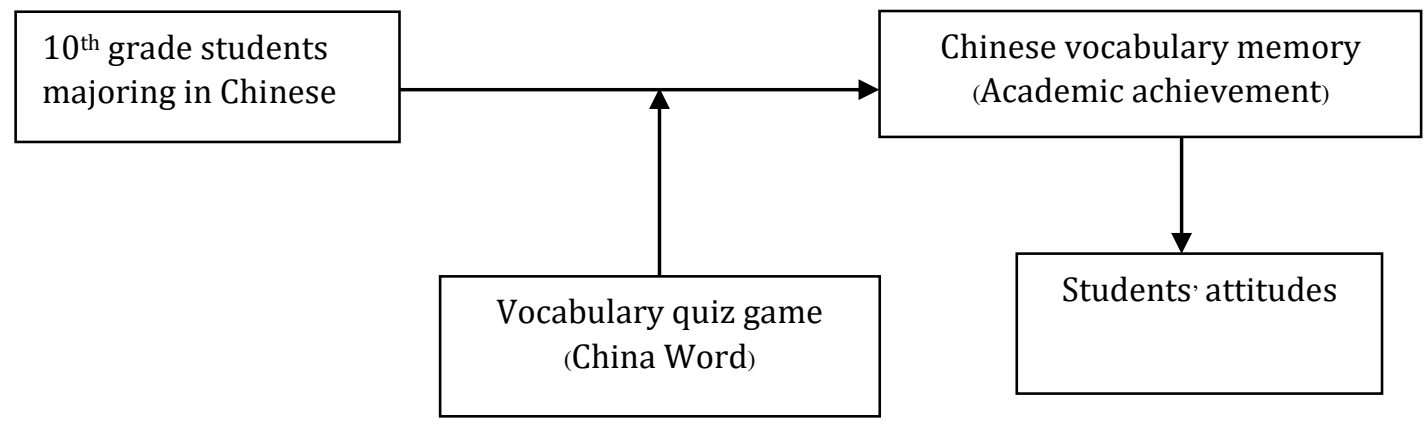

Figure 1. The research concept model for learning with China

From figure 1, this research model shows the relation between the group of 10th grade students who study in Chinese major from a school in Suphanburi Province, Thailand. Also, the main area of this study is improving the Chinese vocabulary memory of students that can be calculate by scores in game and measure the learning outcome. Furthermore, learning with game is lead students to interest in Chinese course. To answer the research question in this research framework, The steps of this research methodology are as follows.

\section{METHODS}

This research is an experimental study in which the research has been designed around the tool developed, i.e., game application to promote Chinese vocabulary learning. Therefore, to accomplish the objective of this research, there are two significant steps to be executed. The first step is to develop the 
game application, and the second step is to evaluate students' satisfaction after using this game. However, to evaluate the satisfaction with the games, the satisfaction questionnaire and assessment tools used to assess game usage must be evaluated based on the Item-Objective Congruence (IOC) index designed by quality assurance specialists.

The experiment was conducted using 2 sample groups of 10th grade students from a school in Suphanburi Province. Every student must pass the pretest examination that contains 30 Chinese vocabulary words to determine the knowledge ranking of each student. Then, some students are randomly selected to study 30 Chinese vocabulary words using the traditional method, and the others study vocabulary words through the game application. After the classes of these two groups, the posttest is performed. Moreover, for the sample group who studied via the game, they must complete the satisfaction questionnaire regarding the game designed to promote Chinese vocabulary learning. Furthermore, before concluding the experiment, the testing results, both the pretest and posttest results, and the scores from the satisfaction questionnaire must be analyzed using statistical analysis methods to determine the success of this research.

\section{Population and Sample}

Since the research focuses on the efficiency of using gaming applications, the target group of this study must be students who have never enrolled in or have no background in Chinese courses. Therefore, students in 10th grade are the most suitable level for this study because the first Chinese course starts in this grade as an elective subject. Therefore, 60 students in 10th grade from a school in Suphanburi Province are randomly selected as participants. These students have an average age of 15 years old and have no experience in learning Chinese language but still want to study Chinese language as an elective subject. Moreover, the game is allowed to learn and play in classroom only. Therefore, researchers can control the experimental environment of the participants.

\section{Research Tools}

Research tools are used in this research: China Word, the pre-posttest for measure the academic achievement, and satisfaction questionnaire.

\section{China Word}

This game is developed to help students memorize Chinese vocabulary by improving their concentration using the game. The game was designed with 2D cartoon characters and is played as a mobile application (Pérez-Colado, et.al, 2019; Valenza, Gasparini, \& Hounsell, 2019). All descriptive functions of China Word are described below.

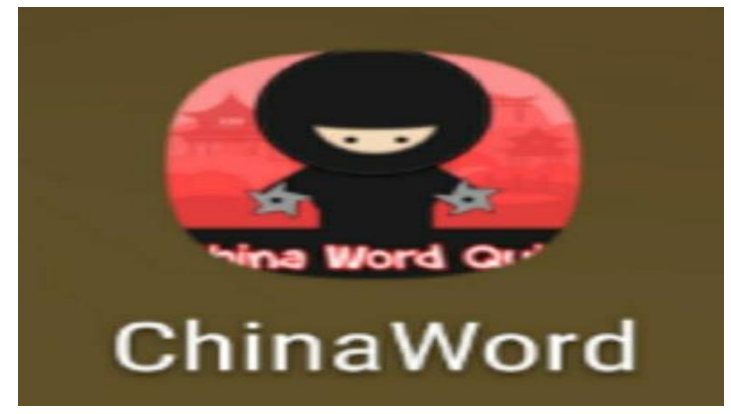

Figure 2. The icon requires one click to start the game.

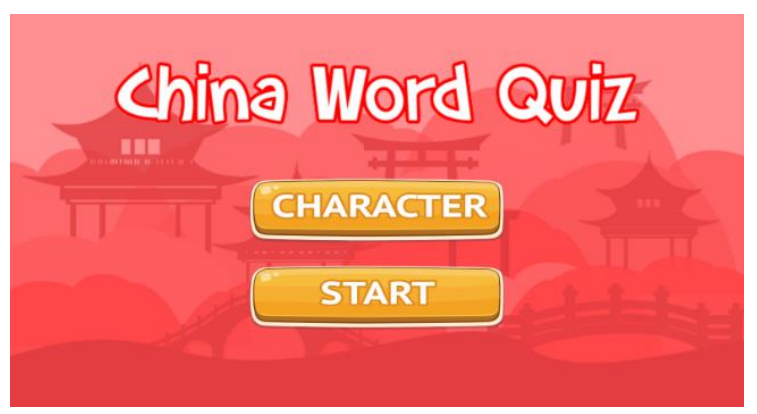

Figure 3. The game's main screen 
This screen is used for start game. If student press the CHARACTER button, the screen will skip to Select Character screen. If student press the START button, the game will start.

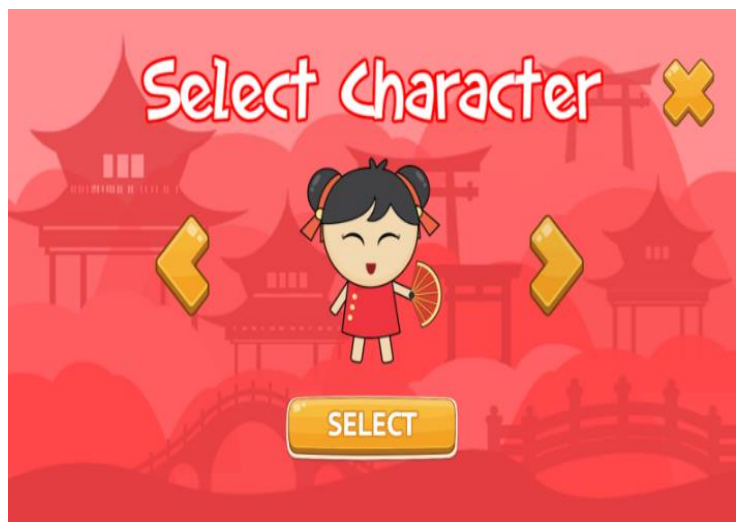

Figure 4. The character selection screen

The student can press the arrow button while choosing the characters and tap the SELECT button to confirm the selection.

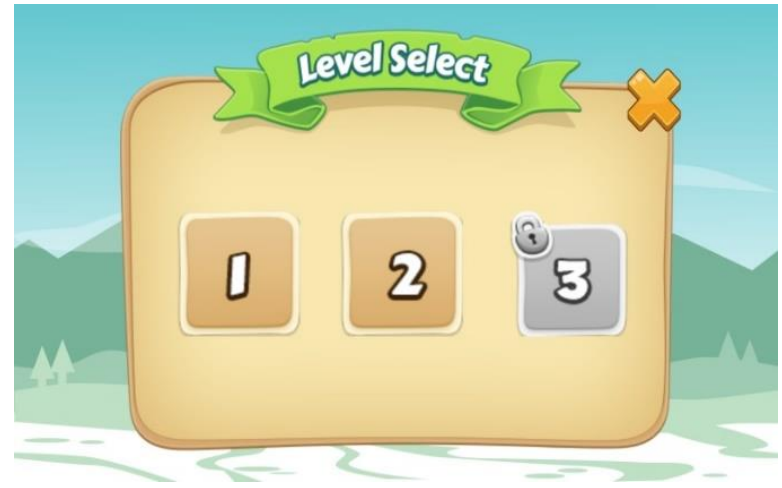

Figure 5. The character selection screen

The student can press the 1 button, the 2 button, or the 3 button to choose the preferred game level.

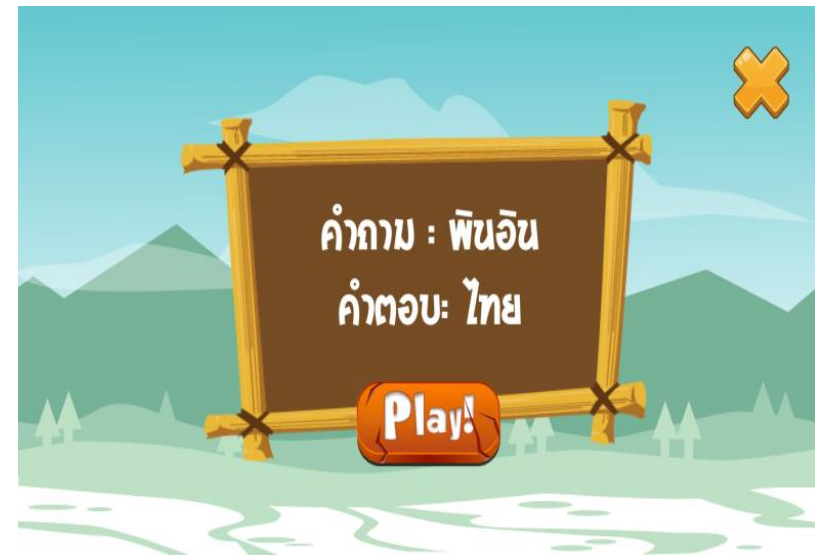

Figure 6. The playing rules screen.

The student can see the rules and how to play game on the screen. Then, pressing the Play button starts the game. 


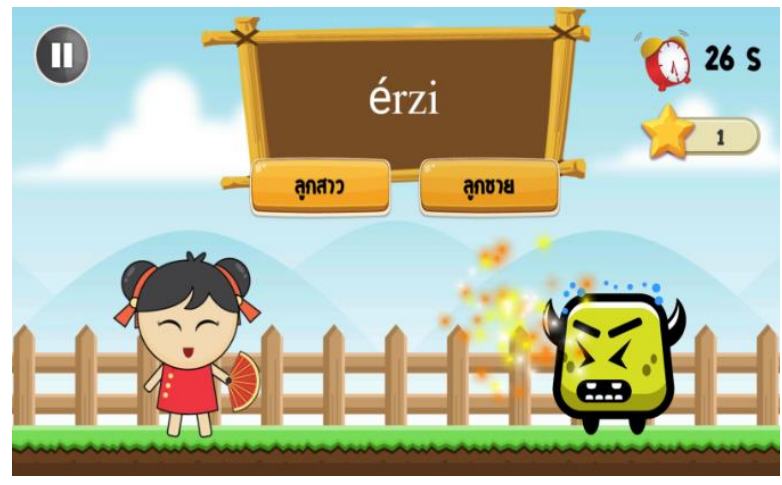

Figure 7. The gameplay screen

Players must answer the question within 30 seconds. If players do not answer within 30 seconds, the game will start over. If students press the right button, the hero will attack a monster and increase their score; otherwise, the monster will attack the hero, and the score will be decreased.

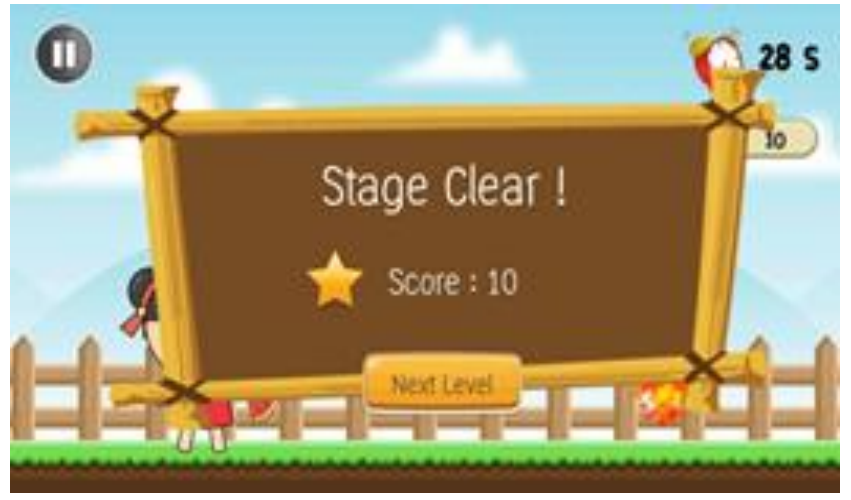

Figure 8. The end game screen.

At the end of the mission, the player can see their score and continue the game.

\section{Pre and Post tests}

Pretest and posttest are used to measure students' Chinese vocabulary memory achievement test. Pretest is test before playing the game and posttest is test after playing the game.

\section{Satisfaction questionnaire}

The interest and preference in the game are measured using the satisfaction rate from students. The satisfaction score is expressed on a scale is measured on ranging from 1 to 5 . The meaning of score can be described. (Uiphanit, Bhattarakosol, Suanpong, Iamsupasit, \& Wongwan, 2020).

- $1.00-1.80=$ poor

- $1.81-2.60=$ fair

- $2.61-3.40=$ good

- $\quad 3.41-4.20=$ very good

- $4.21-5.00=$ excellent

\section{Data analysis}

These data from pretest, posttest, and questionnaire were analyzed by statistic software. The descriptive statistics are the average and standard deviation, which are used to measure the level of satisfaction and interest in learning using the game application. Regarding inferential statistics, a paired sample t-test was used to compare pretest and posttest score. 


\section{RESULTS}

The pretest and posttest are used to compare the students' Chinese vocabulary memorization skills before and after learning with the game (Yeh, \& Wang, 2013; Sriphanason, \& Jewpanich, 2020; Coşar, \& Özdemir, 2020). The hypothesis for this test is "There is no significant difference between the mean score of the control group and the mean score of the experimental group". Additionally, the answer of this hypothesis can be shown in table 1 .

Table 1. Paired samples t-test of the posttests \& pretests of the control and experimental groups.

\begin{tabular}{|l|l|l|l|l|l|l|l|l|l|}
\hline & $\mathbf{N}$ & $\bar{X}$ & S.D. & $\begin{array}{l}\text { Difference } \\
\text { in averages }\end{array}$ & t & Df & Sig & \\
\hline Control group & 30 & 18.60 & 5.18 & 2.97 & 2.436 & 58 & $0.009^{*}$ & \\
\hline $\begin{array}{l}\text { Experimental } \\
\text { group }\end{array}$ & 30 & 21.57 & 5.20 & & \multicolumn{3}{|l|}{} & & \\
\hline
\end{tabular}

Note. $* \mathrm{p}<.05$.

In table 1, the test result shows that the difference of mean score in experimental group is higher than control group in high significant $(\mathrm{p}<0.05)$. Moreover, this result indicates that learners can increase their Chinese vocabulary memorization after learning using the game. Therefore, it can be claimed that the students' vocabulary memorization abilities can be increased when they learn using interesting games.

Table 2. Students' satisfaction and interest after learning with the game.

\begin{tabular}{|l|l|l|l|}
\hline Question & $\bar{X}$ & S.D. & Interpreted \\
\hline $\begin{array}{l}1 \quad \text { The graphics in the game are attractive and } \\
\text { interesting. }\end{array}$ & 4.27 & 0.64 & excellent \\
\hline $\begin{array}{l}\text { 2 Playing the game can help increase learners' interest } \\
\text { in lessons. }\end{array}$ & 4.11 & 0.67 & very good \\
\hline $\begin{array}{l}3 \text { The characters and animation can lead learners to } \\
\text { attend lessons. }\end{array}$ & 3.90 & 1.01 & very good \\
\hline $\begin{array}{l}4 \text { The game display is interesting and suitable for } \\
\text { learners. }\end{array}$ & 4.00 & 0.76 & very good \\
\hline $\begin{array}{l}\text { 5 Playing the game can help players memorize Chinese } \\
\text { vocabulary. }\end{array}$ & 4.47 & 0.68 & excellent \\
\hline $\begin{array}{c}\text { 6 Playing the game can help solve problems in studying } \\
\text { Chinese vocabulary. }\end{array}$ & 4.44 & 0.61 & excellent \\
\hline Average & 4.19 & 0.72 & very good \\
\hline
\end{tabular}

From table 2 shows the improvement of students' Chinese words memorization skill and their interest and preference in the game. Meanwhile, the graphics, characters, and animation stimulate students' attraction and interest in learning with the game. Thus, the game can help learners learn and remember Chinese vocabulary while focusing more on the lessons (Begg, Dewhurst, \& Macleod, 2005; Ebner \& Holzinger, 2007; Rashid, Salleh, \& Noor, 2018).

\section{DISCUSSION AND CONCLUSIONS}

In this research, China Word has been developed to help enhance the quality of learning Chinese vocabulary and to serve as an alternative class material that may make lessons more interesting. The games will also improve learners' enthusiasm in class, decreasing their boredom while learning dry, aged grammar or preventing them from avoiding difficult Chinese vocabulary. Students are able to learn while playing games. This has been proven by many well-known activities and studies. The results of this experiment are as expected. The posttest of the experimental group shows better results than the group's pretest and also better results than those of the control group.

More features can be applied to the gameplay to interact more with users in Chinese conversation lessons. The gameplay can be updated to remain current with the world's latest events to draw more attention from players. 
Similar types of games can be created for other languages, especially languages with difficult alphabets, such as Japanese, Korean, and Hindi. Even those with difficult grammatical structures such as French, Spanish and German can use this kind of application to promote the learning of languages in class for children.

\section{ACKNOWLEDGEMENT}

This paper was supported by Institute for Research and Development, Suan Sunandha Rajabhat University

\section{REFERENCES}

Begg, M., Dewhurst, D., \& Macleod, H. (2005). Game-informed learning: Applying computer game processes to higher education. Innovate: Journal of Online Education, 1(6).

Coşar, M., \& Özdemir, S. (2020). The effects of computer programming on elementary school students' academic achievement and attitudes towards computer. Elementary Education Online, 19(3), 1509-1522.

De Freitas, S. (2018). Are games effective learning tools? A Review of educational games. Educational Technology \& Society,21(2), 74-84.

Ebner, M., \& Holzinger, A. (2007). Successful implementation of user centered game based learning in higher education: An example from civil engineering. Computers \& education, 49(3), 873-890.

Edge, D., Searle, E., Chiu, K., Zhao, J., \& Landay, J. A. (2011, May). MicroMandarin: mobile language learning in context. In Proceedings of the SIGCHI Conference on Human Factors in Computing Systems

(pp. 3169-3178). ACM.

Jin, L. (2018). Digital affordances on WeChat: Learning Chinese as a second language. Computer Assisted Language Learning, 31(1-2), 27-52.

Kanoksilapatham, B. (2011). National survey of teaching Chinese as a foreign language in Thailand. Southeast Asian Ministers of Education Organization.

Prensky, M. (2001). Digital Game-Based Learning. McGraw-Hill Trade.

Pianpitak, S. (2012). The effects of learning activities by using computer adventure game and mnemonic techniques of learning achievement and memory retention in basic Chinese language 1 course for undergraduate students faculty of education silpakorn university. Master thesis in Master of Education Program, Silpakorn University.

Pérez-Colado, V. M., Pérez-Colado, I. J., Freire-Morán, M., Martínez-Ortiz, I., \& Fernández-Manjón, B. (2019). Simplifying the Creation of Adventure Serious Games with Educational Oriented Features. Educational Technology \& Society, 22 (3), 32-46.

Rashid, N. A. M., Salleh, S. M., \& Noor, N. M. (2018). The Role of Game Elements in Improving Jawi Skills through a Mobile Game'G-Jawi'. International Journal of Interactive Mobile Technologies (iJIM), 12(7): 20-30. https://doi.org/10.3991/ijim.v12i7.9636

Sriphanason, S., \& Jewpanich, B. (2020, March). Development of learning achievement in Chinese subject using Chinese game writing skill drill exercise for grade 4/2 students, demonstration school, Suan Sunandha Rajabhat University, Bangkok Thailand. In international academic multidisciplinary research conference in Lucerne 2020 (pp. 195-199).

Terantino, J. M. (2011). YouTube for foreign languages: You have to see this video. Language Learning and Technology, 15(1), 10.

Uiphanit, T., Bhattarakosol, P., Suanpong, K., Iamsupasit, S., \& Wongwan, C. (2020). Chibumons: A Positive Effect on Game to Undergraduate Students. International Journal of Emerging Technologies in Learning (iJET), 15(01), 222-230.

Valenza,M. V., Gasparini, I., \& Hounsell, M. da S. (2019). Serious Game Design for Children: A Set of Guidelines and their Validation. Educational Technology \& Society, 22 (3), 19-31.

Worldometers. (2020) "Countries in the world by population (2020), Worldometers, 2020. [Online] Available: https:// worldometers.info. [Accessed March. 20, 2020].

Wu, T. T., \& Huang, Y. M. (2017). A Mobile game-based English vocabulary practice system based on portfolio analysis. Journal of Educational Technology \& Society, 20(2), 265-277.

Yeh, Y., \& Wang, C. W. (2013). Effects of multimedia vocabulary annotations and learning styles on vocabulary learning. Calico Journal, 21(1),131-144.

Zhu, Y. (2010). Rediscovering the impacts of digital flashcard on Chinese character memorization of beginning US learners. Chinese Teaching in the World, 1, 127-137. 